\title{
Implementation of Problem- Based Learning Model Assisted by E-Modules on Students' Critical Thinking Ability
}

\author{
M. Rahmat ${ }^{1 *}$, Asep Ginanjar Arip ${ }^{2}$, Sofyan H. Nur ${ }^{3}$ \\ 1,2,3 Jurusan Pendidikan Biologi S2 \\ Universitas Kuningan, Kuningan, Indonesia \\ e-mail: rahmat.zueng@gmail.com
}

\begin{abstract}
Education is a significant factor to shape human beings as a whole. The ability to think for humans plays an important role to develop information. The issue of lack of ability to think critically in Sahida Lemah Abang Vocational High School needed to be addressed. One learning model that can be utilized to guide students to think critically is Problem Based Learning (PBL) using an e-module as the resource of learning material. The study aims to examine the implementation of Problem Based Learning model using e-module and its influence on students' critical thinking ability. This study used a quasiexperiment with nonequivalent control group design as its research design. In using the research design, two observations have been conducted; one was before the experiment called Pre-Test $\left(O_{1}\right)$ and one after the experiment of this study called the post-test $\left(\mathrm{O}_{2}\right)$. There are two samples in this study; one is the experimental group and the other is the control group. The study was done in Sahida Lemah Abang Vocational High School. The data was gathered by using tests and observation sheets of the learning process. The result in this study shows averagely that the implementation in each of the learning stages has gained $95.7 \%$ which is in the category of very good value. The most significant difference is from the fifth indicator "developing strategy and tactic", n gain of experimental class and control class is 5.83 and 0.23 respectively. As the result of the hypothesis test is Sig. 0.035 which means that there is a significant difference in students' ability to think critically between the students in the experimental class and the control class, the students in the experimental class think more critically than the students in the control class.
\end{abstract}

Keywords:Problem Based Learning, E-Module, Critical Thinking

\section{Introduction}

Education has an important role in forming people who are God-conscious, intelligent, imaginative, talented, and useful. The aim of national education is to develop the potential of students so that they can think rationally, and have noble character in relation to the values of Pancasila, which uphold the values of truth, goodness, beauty, and religion, as well as being constructive and creative in order to be able to be responsible for advancing the Indonesian nation in adjusting to the demands of modern society is based on democracy and justice (Sukma \& Ibrahim, 2016; Cahyono et al., 2015; Soprapto, 2013)

In an effort to realize the objectives of national education, the learning process must also be considered. The issue of education is a crucial problem faced in this era of globalization so that qualified human resources are needed who master science and technology and are able to drive the industrial sectors in Indonesia (Redhana, 2013). Preparation of quality human resources can be done through education. The quality of education is influenced by several factors, including teachers, students, curriculum, and environmental factors. The teacher is an important factor that determines the quality of education. Demands in the field of education have changed a lot because currently teachers need to organize and implement teaching and learning activities where students can actively build their knowledge. To achieve this goal, a learning system that motivates and develops critical thinking is needed (Redhana, 2013).

Critical thinking is the process of thinking of an individual to investigate the reasons that exist and analyse the information available to arrive at a conclusion so that the individual can make decisions and assessments (Ali-Abadi et al., 2020; DeWaelsche, 2015; Pursitasari et al., 2020).Therefore, critical thinking is a combination of abilities, knowledge, attitudes, skills, and

\footnotetext{
${ }^{*}$ Corresponding author.
}

Received 09 December 2019; Accepted 10 July 2020; Available online 1 September 2020 (C) 2020 JPI. All Rights Reserved 
processes so that individuals who think critically have the ability to ask questions correctly, reduce relevant information, think logically for the information they have obtained, and make conclusions and decisions and reliable assessments (Pursitasari et al., 2020).Critical thinking skills will arise in students when during the learning process in the classroom, the teacher designs patterns of interaction and communication using a method that emphasizes more on seeking effective information by the students.

The low achievement of student competencies at SMK Sahida Lemah abang especially in class $X A K L$ is due to the monotonous learning process that only relies on explanations from the teachers. As a result, there are still many learning goals that have not yet achieved the KKM (Minimum Criteria of Learning Mastery). Based on this evidence, efforts are needed to develop students' thinking abilities, so that the students can be freer to think in search of material and solutions to a problem related to the subject matter. Thus, students can be more critical and creative in the learning process.

To develop the process of thinking in a learning process, it is necessary to have a model or learning theory that supports the thinking framework. One model that can be used to guide students to think creatively, critically, and at high ordered thinking is Problem Based Learning (PBL).Problem Based Learning is a learning model that is based on the many problems that require authentic inquiry, that is, investigations that require real resolution of real problems (Nurhidayati et al., 2018; Phungsuk et al., 2017; Abdullah et al., 2015; Ari \& Katrancı, 2014). Through the Problem Based Learning model, students are trained to work together as a group to find out problem solving and most importantly they can improve their ability to solve problems and make conclusions as well as decisions (Han et al., 2016; Haji et al., 2015;Jalani \& Sern, 2015)

PBL can influence and enhance students' critical thinking (Joshi et al., 2020;Andersen et al., 2019). There are several studies on PBL on students' critical thinking. Like the research conducted by (Happy \& Widjajanti, 2014) which states that PBL is effective in increasing critical thinking skills. Then research conducted by (Noprianda et al., 2019)which states that there are significant differences in the critical thinking skills of students taught with PBL learning models. In addition to the learning model, one of the factors supporting the success of learning in the classroom is learning materials that can increase student reading interest. This study has found that the majority of students are reluctant to open their textbooks because they are too ordinary and monotonous. Most students would rather prefer to open their gadgets rather than read their books. Based on this evidence, one solution to tackle the problem is by using the e-modules. E-modules is a module based on computer technology and contains chunks of learning material followed by questions in each chunk to make users easier to understand the material and allows displaying or loading images, audio, video and animation as well completed formative tests or quizzes enable automatic feedback immediately (Nufus et al., 2020; Sofyan et al., 2019;:Patel et al., 2018; Li et al., 2016; Suarsana \& Mahayukti, 2013)

Based on the problems above, one of the efforts that can be done is the use of learning models that can foster students' thinking abilities, a Problem Based Learning (PBL) learning model PBL learning model can improve students' critical thinking. That is because in this PBL learning model students are given problems and then asked to find solutions to these problems so students can make conclusions and decisions. In this study, PBL learning models are assisted by e-modules. The use of e-modules can help students in the learning process. The objective of this research is to analyze the implementation of the Problem Based Learning (PBL) using e-module on students' critical thinking skills.

\section{Method}

The research design used in this study is Non-equivalent Control Group Design (Sugiono, 2015). The model aims to find out and compare the data results of the values before and after a treatment on the same subject. In this design, observations are carried out twice namely before and after the experiment. The observations made before the experiment $\left(\mathrm{O}_{1}\right)$ are called Pre-Test, and observations after the experiment $\left(\mathrm{O}_{2}\right)$ are called post-tests. The research is carried out using two sample groups namely the experimental group and control group. 
The population of this study is all students in the Sahida Lemahabang Vocational School in Cirebon, there were 475 students. This study uses a sample of class X AKL as the experimental class and class X OTKP as the control class in the Sahida Lemahabang Vocational School. The sampling technique that is used in this study is a non-probability sampling. Data collecting instruments in this study are observation and written test. Observations would be done to get the data to measure the implementation of the learning process using the Problem Based Learning (PBL) model. The observations were conducted with the help of observers.

In this study, the data collection process includes a variety of activities, namely subject studies, model formulation, e-learning modules media study, analysis of concepts of the subject matter, analysis of student critical thinking indicators, description of evaluation tools, expert validation and design of teaching materials. The trial phase of the design of teaching materials using models and learning media have been made. A pretest is conducted followed by a teaching and finally a post-test. After all data is obtained, then the data is analyzed to obtain answers to the research question.

The test questions in this study were conducted to determine the test of students' critical thinking skills. There are 10 long answer questions. The instrument used in the form of pretest and post-test conducted to measure the increase in students' critical thinking skills. Scoring criteria used to obtain critical thinking skills data is a modified rubric score contained in Table 1.

Table 1. Critical Thinking Skill Scoring Guidance

\begin{tabular}{cl}
\hline Score & \multicolumn{1}{c}{ Criteria } \\
\hline $\mathbf{4}$ & Answer/explanation/conclusion are more than $75 \%$ correct \\
$\mathbf{3}$ & Answer/explanation/conclusion are $50 \%-75 \%$ correct \\
$\mathbf{2}$ & Answer/explanation/conclusion are $25 \%-49 \%$ correct \\
$\mathbf{1}$ & Answer/explanation/conclusion are less than $25 \%$ correct \\
$\mathbf{0}$ & Answer/explanation/conclusion are incorrect/ not answered \\
\hline
\end{tabular}

\section{Results and Discussion}

This research was conducted to study and analyze students' critical thinking skills in terms of the learning process by using the Problem Based Learning (PBL) and by using the lecturing method.

\section{Implementation of Problem Based Learning (PBL) Model}

The implementation of the stages of the learning process is analyzed using observational data made by the observer using the observation format of the implementation of the Problem Based Learning (PBL). The results obtained from the learning process at the $1^{\text {st }}, 2^{\text {nd }}$, and $3^{\text {rd }}$ meetings in Table 2.

Table 2. The Percentage of the Learning Model Implementation Problem Based Learning (PBL)

\begin{tabular}{lc}
\hline \multicolumn{1}{c}{ Activities } & \multicolumn{2}{c}{ Percentage } \\
\cline { 2 - 2 } & Yes (\%) \\
\hline Preliminary & 100 \\
Main Activity & \\
1. Students' orientation on the problem & 100 \\
2. Organizing students to learn & 100 \\
3. Guiding individual/ group investigation & 100 \\
4. Developing and presenting the product & 100 \\
\hline
\end{tabular}




\begin{tabular}{lccc}
\hline & Activities & \multicolumn{2}{c}{ Percentage } \\
\cline { 2 - 3 } & & Yes (\%) & No (\%) \\
\hline $\begin{array}{l}\text { 5. Analyzing and evaluating the process of problem } \\
\text { solving }\end{array}$ & 80 & 20 \\
Closing & & 90 & 10 \\
\hline & Average & 95.7 & 4.3 \\
\hline
\end{tabular}

Data on the percentage of Problem Based Learning (PBL) implementation above shows the average value of each stage done is $95.7 \%$, which can be seen that the PBL implementation is between the percentages of $81 \%-100 \%$; meaning it is in a very good category.

The implementation has successfully been done because it is supported by several factorsamong others are, the problems discussed in the learning process are not new which means the students face those problems in their daily life within their environments (authentic), the teacher has explained how the learning process will be done using the Problem Based Learning (PBL) model, the students are accustomed to learning both individually and in a group discovering and discussing the learning process, a supportive environment and community help the students to actively collaborate.

\section{The Influence of Problem Based Learning (PBL) Learning Model on Students' Critical Thinking Abilities}

The results of the average value of the initial test and the final test of critical thinking skills in the experimental and control groups are presented in table 3.

Table 3. The Difference of the Test Result between Experimental Class and Control Class in Each Indicator

\begin{tabular}{lccccc}
\hline \multirow{1}{*}{ Data } & \multicolumn{5}{c}{ Indicators } \\
\cline { 2 - 6 } & 1 & 2 & 3 & 4 & 5 \\
\hline Sum & -0.26 & 3 & 2.5 & 2.66 & 5.83 \\
Average & -0.01 & 0.12 & 0.1 & 0.1 & 0.23 \\
\hline
\end{tabular}

Indicators:

$1=$ Giving simple explanations

2 = Building basic skills

$3=$ Concluding

$4=$ Giving further explanations

5 = Developing strategy and tactic

Based on table 3, the most significant difference from the sum of the $n$ gain values of the experimental class and the control class is found in indicator five, namely "Developing strategies and tactics" of 5.83. The second most significant difference is in indicator two: "Building basic skills" of 3 and so on. While the biggest difference in the average value of the $\mathrm{n}$ gain of the experimental class and the control class is in indicator five, namely "Developing strategies and tactics" of 0.23 . The second-largest average difference is in indicator two, "Building basic skills" of 0.12 , and so on. When it is seen as a whole, there are indeed differences in improvement from each indicator, but in principle, the critical thinking skills of the experimental class as a whole are better when compared to the control class.

Comparing the difference from both averages is to know the significant difference between experimental class and control class which needs hypothetical test. The result of comparison test (t-test) can be seen in Table 4. 
Table 4. Comparison Test (t-test)

\begin{tabular}{lccccc}
\hline & $\mathbf{F}$ & Sig. & $\mathbf{t}$ & $\mathbf{d f}$ & Sig. (2 -tailed) \\
\hline Equal variances assume & 0,017 & 0,897 & 2,173 & 48 & 0,035 \\
$\begin{array}{l}\text { Equal variances not } \\
\text { assumed }\end{array}$ & & & 2,173 & 47,8 & 0,035 \\
\hline
\end{tabular}

Based on the result of the test presented in the table, $F$ value that assumed two variables are similar is 0.17 with t score 2.173 and with the degrees of freedom (df) 23 and with $\alpha=0.05$ Sig. 0.035 is obtained. Because Sig. 0.035 is less than 0.05 , it means there is a significant difference in students' critical thinking when using PBL learning model and lecturing. Thus, using PBL is better than lecturing.

Based on the results of the analysis, it can be seen that the percentage of the implementation of Problem Based Learning (PBL) assisted by e-modules has been done is $95.7 \%$, which can be seen that the implementation of the PBL assisted e-module learning model is between a percentage of $81 \%-100 \%$; that means it's in a very good category. In the experimental class, the Problem Based Learning model assisted by e-modules also leads students to learn to work together in groups, so students can discuss about problems so they can find solutions to problems according to the level of student understanding.Through the Problem Based Learning model, students are trained to work together as a group to find out problem solving and most importantly they can improve their ability to solve problems and make conclusions as well as decisions (Han et al., 2016; Haji et al., 2015;Jalani \& Sern, 2015).

The results of this study are in line with research conducted by (Happy \& Widjajanti, 2014) which states that the PBL learning model is effective in increasing critical thinking skills. Other studies conducted by (Kumullah et al., 2018) stated that PBL learning models affect the ability of students to think critically. Other studies that are in line are research conducted by (Santi et al., 2016) which states that the use of e-modules in learning can improve students' critical thinking. Other studies conducted by (Phungsuk et al., 2017) states that problem-based learning via a virtual learning environment enhanced learning ability and problem-solving skills among students in the Photography for Communication Arts course. Furthermore, (Jalani \& Sern, 2015) states based on the positive results obtained from a previous study, an PBL model was proposed which contains three important components and the five elements of implementation. PBL emphasizes that learning achievement is maximized and at the same time the necessary amount of cognitive load is minimized in achieving more efficient and effective learning processes.

This study is also in line with research conducted by (Sari et al., 2015) which states that PBL learning models assisted by pictorial card media have an effect on students' critical thinking. In addition, other studies that are in line are research conducted by (Munandar et al., 2018) which states that there is an influence of PBL learning models on students' critical thinking skills including students focusing on questions, being able to analyze arguments or identifying reasons, being able to consider the results of induction, and evaluating the results of consideration also provides reasons.

Based on the analysis results, it can be seen that the critical thinking skills of the experimental class as a whole are better when compared to the control class. Increased students' critical thinking skills on each indicator showed a variety of improvement. This is because students are required to solve problems so that it makes students' intellectual abilities increase, take responsibility in their learning, connect theories, analyze situations, apply knowledge and develop abilities in making assignments objectively. The use of e-modules also has an effect on increasing students' critical thinking.

\section{Conclusion and Suggestions}

Based on the analysis and processing of data on the results of research that has been conducted at the Sahida Lemahabang Vocational School, Lemahabang Sub-District, Cirebon District, it can be concluded that the Problem Based Learning (PBL) model can be 
implemented very well because the problems discussed in the learning process are not new, the teacher has explained about how the learning process will be done, students are accustomed to learning in groups, and learning environment and community are supportive. The Problem Based Learning (PBL) learning model, when it is done well following its stages, can improve students' critical thinking skills, especially on the indicator "Develop strategies and tactics".

\section{Acknowledgements}

Praises and gratitude only to Allah SWT, because of His Mercy and Blessing we can finish our research and write our article under the title "Implementation of Problem Based Learning (PBL) Model assisted by E-module on Students' Critical Thinking Ability". This research has been successfully conducted with the support of the following people whom we are thankful for:(1) the director of Postgraduate Kuningan University, (2) the Chairman of Biology Postgraduate Study Program at Kuningan University, (3) the first thesis supervisor Dr.agr. Asep Ginanjar Arip, M.Si, (4) the second thesis supervisor Dr. H. Sofyan H. Nur, M.Si, (5) all wonderful people who have made this research successful. We hope that this study will be beneficial to the development of the Biology Postgraduate Study Program and Kuningan University as well as to society.

\section{References}

Abdullah, D. I., Z, M., \& H, S. (2015). Keefektifan model pembelajaran problem based learning bernuansa etnomatematika terhadap kemampuan pemecahan masalah siswa kelas VIII. Unnes Journal of Mathematics Education., 4(3). https://doi.org/10.15294/ujme.v4i3.9056

Ali-Abadi, T., Babamohamadi, H., \& Nobahar, M. (2020). Critical thinking skills in intensive care and medical-surgical nurses and their explaining factors. Nurse Education in Practice, 45(March), 102783. https://doi.org/10.1016/j.nepr.2020.102783

Andersen, A. L., Brunoe, T. D., \& Nielsen, K. (2019). Engineering education in changeable and reconfigurable manufacturing: using problem-based learning in a learning factory environment. Procedia CIRP, 81, 7-12. https://doi.org/10.1016/j.procir.2019.03.002

Ari, A. A., \& Katrancı, Y. (2014). The opinions of primary mathematics student-teachers on problem-based learning method. Procedia - Social and Behavioral Sciences, 116(5), 1826-1831. https://doi.org/10.1016/j.sbspro.2014.01.478

Cahyono, L. E., Budiwibowo, S., \& Murwani, J. (2015). Analisis penerapan 8 standar nasional pendidikan pada SMP Negeri 2 Dolopo kabupaten Madiun. Jurnal Akutansi Dan Pendidikan, 4(2). https://doi.org/http://doi.org/10.25273/jap.v4i2.684

DeWaelsche, S. A. (2015). Critical thinking, questioning and student engagement in Korean university English courses. Linguistics and Education, 32, 131-147. https://doi.org/10.1016/j.linged.2015.10.003

Haji, A. G., Safriana, \& Safitri, R. (2015). The use of problem based learning to increase students' learning independent and to investigate students' concept understanding on rotational dynamic at students of SMA Negeri 4 Banda Aceh. Jurnal Pendidikan IPA Indonesia, 4(1), 67-72. https://doi.org/10.15294/jpii.v4i1.3503

Han, S., Rosli, R., Capraro, M. M., \& Capraro, R. M. (2016). The effect of Science, technology, engineering and mathematics (STEM) project based learning (PBL) on students' achievement in four mathematics topics. Journal of Turkish Science Education, 13(Specialissue), 3-30. https://doi.org/10.12973/tused.10168a

Happy, N., \& Widjajanti, D. B. (2014). Keefektifan pbl ditinjau dari kemampuan berpikir kritis dan kreatif matematis, serta self-esteem siswa SMP. Jurnal Riset Pendidikan Matematika, 1(1), 48. https://doi.org/10.21831/jrpm.v1i1.2663

Jalani, N. H., \& Sern, L. C. (2015). The example-problem-based learning model: applying cognitive load theory. Procedia - Social and Behavioral Sciences, 195, 872-880. 
https://doi.org/10.1016/j.sbspro.2015.06.366

Joshi, A., Desai, P., \& Tewari, P. (2020). Learning analytics framework for measuring students' performance and teachers' involvement through problem learning in engineering education. Procedia Computer Science, 172, 954-959. https://doi.org/10.1016/j.procs.2020.05.138

Kumullah, R., Djatmika, E. T., \& Lia, Y. (2018). Kemampuan berpikir kritis dan penguasaan konsep siswa dengan problem based learning pada materi sifat cahaya". Teori, Pnelitian Dan Pengembangan, 3(2014), 1583-1586. http://dx.doi.org/10.17977/jptpp.v3i12.11798

Li, W., Cashell, A., Jaffray, D. A., \& Moseley, D. (2016). Development and implementation of an electronic learning module for volumetric image-guided radiation therapy. Journal of Medical Imaging and Radiation Sciences, 47(1), 43-48. https://doi.org/10.1016/j.jmir.2015.12.001

Munandar, H., Sutrio, S., \& Taufik, M. (2018). Pengaruh model pembelajaran berbasis masalah berbantuan media animasi terhadap kemampuan berpikir kritis dan hasil belajar fisika siswa SMAN 5 Mataram tahun ajaran 2016/2017. Jurnal Pendidikan Fisika Dan Teknologi, 4(1), 111. https://doi.org/10.29303/jpft.v4i1.526

Noprianda, M., Noor, M. F., \& Zulfiani, Z. (2019). Keterampilan berpikir kritis siswa model pembelajaran problem based learning dan sains teknologi masyarakat pada konsep virus. Edusains, 8(2), 182-191. https://doi.org/10.15408/es.v8i2.3892

Nufus, H., Susilawati, S., \& Linda, R. (2020). Implementation of e-module stoiciometry based on kvisoft flipbook maker for increasing understanding study learning concepts of class $\mathrm{X}$ senior high school. Journal of Educational Sciences, 4(2), 368-379. http://dx.doi.org/10.31258/jes.4.2.p.261-272

Nurhidayati, A., Putro, S. C., \& Widiyaningtyas, T. (2018). Penerapan model PBL berbantuan e-modul berbasis flipbook dibandingkan berbantuan bahan ajar cetak pengaruhnya terhadap hasil belajar pemrograman siswa SMK. Teknologi Dan Kejuruan: Jurnal Teknologi, Kejuruan, Dan Pengajarannya, 41(2), 130-138. https://doi.org/10.17977/um031v41i22018p130

Patel, S. R., Margolies, P. J., Covell, N. H., Lipscomb, C., \& Dixon, L. B. (2018). Using instructional design, analyze, design, develop, implement, and evaluate, to develop elearning modules to disseminate supported employment for community behavioral health treatment programs in New York State. Frontiers in Public Health, 6. https://doi.org/10.3389/fpubh.2018.00113

Phungsuk, R., Viriyavejakul, C., \& Ratanaolarn, T. (2017). Development of a problem-based learning model via a virtual learning environment. Kasetsart Journal of Social Sciences, 38(3), 297-306. https://doi.org/10.1016/j.kjss.2017.01.001

Pursitasari, I. D., Suhardi, E., Putra, A. P., \& Rachman, I. (2020). Enhancement of student's critical thinking skill through science context-based inquiry learning. Jurnal Pendidikan IPA Indonesia, 9(1), 97-105. https://doi.org/10.15294/jpii.v9i1.21884

Redhana, I. W. (2013). Model pembelajaran berbasis masalah dan pertanyaan socratik untuk meningkatkan keterampilan berpikir kritis siswa. Jurnal Cakrawala Pendidikan, 3, 351365. https://doi.org/10.21831/cp.v0i3.1136

Santi, B., Murbangun, N., \& Edy, C. (2016). Guided inquiry berbantuan e-modul untuk meningkatkan keterampilan berpikir kritis. Journal of Innovative Science Education, 1(1), 1-9. https://journal.unnes.ac.id/sju/index.php/jise/article/view/14264

Sari, I. P., Yushardi, Y., \& Subiki, S. (2015). Penerapan model problem based learning ( PBL ) berbantuan media kartu bergambar terhadap kemampuan berpikir kritis dan hasil belajar siswa dalam pembelajaran fisika SMK Negeri di kabupaten Jember. Jurnal Pembelajaran Fisika,4(3), 268-273. http://jurnal.unej.ac.id/index.php/JPF/article/view/2649 
Sofyan, H., Anggereini, E., \& Saadiah, J. (2019). Development of e-modules based on local wisdom in central learning model at kindergartens in Jambi city. European Journal of Educational Research, 8(4), 1137-1143. https://doi.org/10.12973/eu-jer.8.4.1137

Soprapto, S. (2013). Landasan aksiologis sistem pendidikan nasional Indonesia dalam perspektif filsafat pendidikan. Jurnal Cakrawala Pendidikan, 266-276. https://doi.org/https://dx.doi.org/10.21831/cp.v0i2.1485

Suarsana, I. M., \& Mahayukti, G. A. (2013). Pengembangan e-modul berorientasi pemecahan masalah untuk meningkatkan keterampilan berpikir kritis mahasiswa. Jurnal Pendidikan Indonesia, 2(2), 193. https://doi.org/http://dx.doi.org/10.23887/jpi-undiksha.v2i2.2171

Sugiono. (2015). Metode Penelitian Pendidikan(Pendekatan Kuantitati, Kualitatif dan R\&D). Alfabeta.

Sukma, M. C., \& Ibrahim, M. (2016). Developing materials for active learning of guided inquiryintegrated bowling campus on the topic of sense of hearing and sonar system of living organism. Jurnal Pendidikan IPA Indonesia, 5(2), 256-260. https://doi.org/10.15294/jpii.v5i2.5981 